\title{
Обґрунтування необхідності професійної підготовки тренерів до ведення навчально- тренувального процесу в жіночому міні-футболі 3 урахуванням гендерної диференціації
}

\author{
Євгенія Шаповал \\ Ліна Голуб
}

Полтавськийнаціональнийпедагогічнийуніверситет

імені В. Г. Короленка, Полтава, Україна

\begin{abstract}
Мета: є обгрунтування шляхів удосконалення профресійної діяльності майбутніх тренерів-викладачів жіночих команд з міні-фрутболу у нових організаційно-управлінських умовах.

Матеріал і методи: в експерименті взяли участь 226 дівчат 11-14 років. Визначені контрольна та експериментальна групи були рівномірно розподілені за рівнями сфрормованості рухових навичок дівчат 11-14 років шляхом довільного вибору учасників. Матеріали дослідження впроваджено в навчально-тренувальний процес Коцюбинської ДЮСШ Київської області, Комунального закладу ДЮСШ імені О. Бутовського Полтавської обласної ради, Комунального закладу ДЮСШ № 8 Харківської міської ради, Ірпінської ДЮСШ Ірпінської міської ради. У процесі дослідження використовувалися теоретичні, емпіричні та методи математичної статистики для кількісного та якісного аналізу емпіричних даних. Результати: розроблено узагальнену схему процесу фрормування рухових навичок у міні-фрутболі. З'ясовано вимоги до рівня професійної кваліфрікації й компетентності, а також організації профресійної підготовки майбутніх тренеріввикладачів: оволодіння необхідними професійними знаннями, уміннями, навичками в галузі фрізичного виховання та спорту.
\end{abstract}

Висновки: необхідність профресійного становлення майбутніх тренерів-викладачів у процесі фрахової підготовки зумовлює розв'язання педагогічних завдань щодо розвитку профресійної компетентності, профресійно важливих якостей, формування готовності до тренерсько-викладацької діяльності, профресійного самовдосконалення та самореалізації.

Ключові слова: профресійна діяльність, навчально-тренувальний процес, міні-футбол, дифреренційований підхід, рухові навички, дівчата-футбболістки.

\section{Вступ}

Незважаючи на зростаючу у світі популярність жіночого спорту взагалі, і міні-футболу, зокрема, є обмежена кількість як досліджень, так і методичних рекомендацій, що стосуються підготовки жінок у міні-фрутболі.

Вивчення комплексу науково-методичних джерел та матеріалів з досвіду роботи сучасних дитячо-юнацьких спортивних шкіл (ДЮСШ) засвідчили суттєві суперечності між положеннями сучасної теорії навчання руховим діям (Н. Бернштейн, Т. Круцевич, О. Худолій та інші) і практичною роботою педагогів у фізичному вихованні, які розв'язують завдання навчання руховим діям за рахунок великої кількості повторень вправи в стабільних умовах навчальної діяльності. Теоретичні та методичні засади підготовки юних спортсменок вивчали вітчизняні вчені Г.Лисенчук, Л. Матвєєв, В. Платонов, Л. Сергієнко та інші. Основи методики розвитку рухових якостей підлітків розглядали М. Линець, Р. Мішаровський, С. Присяжнюк, О. Тимошенко та інші [9].

Відсутність необхідної методичної і спеціальної літератури з жіночого міні-фрутболу ускладнює можливості правильноїорганізаціїнавчально-тренувальногопроцесу, побудовитренувальнихзанятьтаоптимальневизначення їхнього змісту іспрямованості.

Доступність цього виду спорту, простота інвентарю й обладнання, з одного боку, і величезна емоційність гри, з іншого боку, завоювали жіночому міні-футтболу велику кількість прихильників та уболівальників. Водночас значна різноманітність ігрових ситуацій, високі вимоги до загальної фрізичної підготовленості, швидкості, витривалості, сили та спритності спортсменок поряд із недостатньо вивченим впливом занять міні-фрутболом на жіночий організм, спонукають шукати найбільш доцільні підходи до тренувального процесу футболісток[9].

Метою дослідження є обґрунтування шляхів удосконалення професійної діяльності майбутніх тренеріввикладачів жіночих команд 3 міні-футболу у нових організаційно-управлінських умовах.

\section{Матеріал і методи дослідження}

В експерименті взяли участь 226 дівчат 11-14 років. Визначені контрольна та експериментальна групи були рівномірно розподілені за рівнями сформованості рухових навичок дівчат 11-14 років шляхом довільного вибору учасників. Матеріали дослідження впроваджено в навчально-тренувальний процес Коцюбинської ДЮСШ Київської області, Комунального закладу ДЮСШ імені О. Бутовського Полтавської обласної ради, Комунального закладу ДЮСШ № 8 Харківської міської ради, Ірпінської ДЮСШ Ірпінської міської ради. У процесі дослідження 


\section{СЛОБОЖАНСЬКИЙ НАУКОВО-СПОРТИВНИЙ ВІСНИК:}

\section{Матеріали XIX Міжнародної науково-практичної конференції «Фізична культура, спорт і здоров'я: стан, проблеми та перспективи»}

використовувалися теоретичні, емпіричні та методи математичної статистики для кількісного та якісного аналізу емпіричних даних [9].

\section{Результати дослідження}

Сучасні задачі жіночого міні-фрутболу диктують необхідність прискореного вивчення фракторів, які впливають на спортивний результат, визначаючи їх значущість для представників різних ігрових амплуа [7, 9].

Розроблений комплекс критеріїв дозволив виділити чотири рівні сформованості рухових навичок дівчат засобами міні-фрутболу: початковий, середній, достатній високий. Рівень сформованості рухових навичок ми розглядали як характеристику та взаємодію означених критеріїв.

На основі узагальнення теоретичного матеріалу нами розроблено узагальнену схему процесу формування рухових навичок у міні-фрутболі. На стадії формування навички поступово усуваються зайві рухи, удосконалюється міжм'язова координація, рухи стають точнішими у просторі, часі і за зусиллями. Усі рухи відтворюються невимушено, плавно, з високою точністю і стабільно. 3 окремих навичок фрормується вміння виконувати цілісну рухову діяльність, або вміння вищого порядку (див. рис. 1).

Найскладнішою в цьому сенсі стає проблема вибору критеріїв диференціації. Основне завдання диференційного навчально-тренувального процесу полягає в тому, щоб забезпечити максимально продуктивну діяльність кожного спортсмена, надати оптимальний руховий режим, повніше мобілізувати їх здібності. Урахування ступеня статевого дозрівання, фрізичного розвитку, характеру адаптації до м'язової діяльності дає змогу більшою мірою індивідуалізувати навчально-тренувальнийпроцес.

Розроблена нами схема реалізації поліфакторно диференціації навчально-тренувального процесу в мініфрутболі наведена на рисунку 2.

Поліфакторна диференціація навчальнотренувального процесу з міні-футболу розглядається як процес розвитку рухових навичок спортсменів усистемносинергетичній єдності статевої, вікової, індивідуальнотипологічної диференціації, розподілу за психологічними параметрами, за рівнем розвитку рухових якостей та за ступенем тренованості.

Рівнева диференціація характеризується такою організацією навчально-тренувального процесу, під час якого спортсмени, займаючись за однією програмою, мають право й можливість засвоїти ії̈ на різних рівнях, але не нижче рівня обов'язкових вимог. За такою диференціацією навчально-тренувальний процес має специфічну спрямованість у галузь стійких інтересів, схильностей здібностей задля їхнього максимального розвитку.

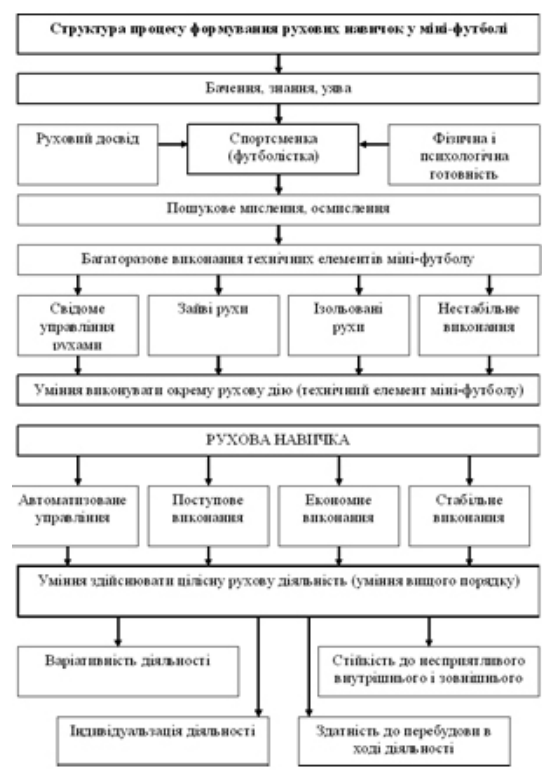

Рис. 1. Узагальнена схема процесу формування рухових навичок у міні-фрутболі

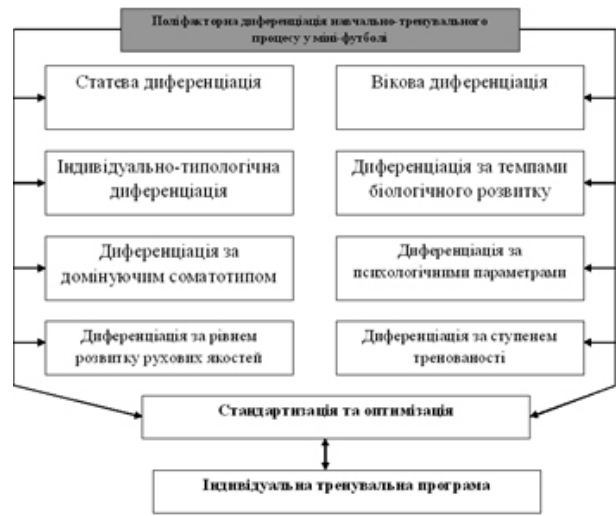

Рис. 2. Схема реалізації поліфакторної диференціації навчально-тренувального процесу в міні-футболі

Як помітно 3 аналізу даних таблиці 1, контрольна та експериментальна групи є однорідними за вихідними даними сформованості рухових навичок дівчат 11-14 років. Однорідність контрольної і експериментальної груп засвідчує також критеріальний аналіз сформованостірухових навичок (табл. 1).

Отже, результати діагностувального зрізу стану рухових навичок засвідчили загалом низький рівень сформованості їх показників, більшість з яких знаходяться на низькому та початковому логічних рівнях, високий рівень сорормованості компетентності за групами показників

Таблиця 1

Дані розподілу спортсменок контрольної та експериментальної груп за рівнями і групами показників сформованості рухових навичок до експерименту (у \%)

\begin{tabular}{|c|c|c|c|c|c|c|c|c|}
\hline \multirow{2}{*}{$\begin{array}{c}\text { Критерій сформованості } \\
\text { рухових навичок }\end{array}$} & \multicolumn{2}{|c|}{ Початковий } & \multicolumn{2}{|c|}{ Середній } & \multicolumn{2}{|c|}{ Достатній } & \multicolumn{2}{|c|}{ Високий } \\
\hline & КГ & EГ & КГ & $\mathrm{E \Gamma}$ & КГ & EГ & КГ & EГ \\
\hline Гносеологічний & 45 & 44 & 25 & 26 & 20 & 21 & 10 & 9 \\
\hline Психологічний & 33 & 35 & 36 & 34 & 19 & 17 & 12 & 14 \\
\hline $\begin{array}{l}\text { Антропометрично- } \\
\text { функціональний }\end{array}$ & 24 & 25 & 37 & 36 & 21 & 20 & 18 & 19 \\
\hline Руховий (моторний) & 44 & 44 & 25 & 27 & 20 & 18 & 11 & 11 \\
\hline Технічний & 39 & 37 & 34 & 35 & 16 & 16 & 11 & 12 \\
\hline Тактичний & 43 & 44 & 28 & 27 & 20 & 19 & 9 & 10 \\
\hline
\end{tabular}




\section{СЛОБОЖАНСЬКИЙ НАУКОВО-СПОРТИВНИЙ ВІСНИК:}

\section{Матеріали XIX Міжнародної науково-практичної конференції «Фізична культура, спорт і здоров'я: стан, проблеми та перспективи»}

виявлено в незначної кількості досліджуваних. Дані показники свідчать, в першу чергу, про недосконалість методичного підходу тренера-викладача до навчальнотренувального процесу юних фрутболістів.

3 метою підвищення ефективності учбовотренувального процесу дівчат 11-14 років в міні-футболі нами було упроваджено в програму ДЮСШ авторську комплексну фрункціонально-діагностичну методику навчально-тренувального процесу на принципах диференційованого підходу, перевірена вона в ході дослідноекспериментальної роботи. Експериментальна перевірка пропонованої комплексної функціонально-діагностичної методики навчально-тренувального процесу відбувалася в два етапи $[7,9]$.

Після впровадження комплексної функціональнодіагностичної методики навчально-тренувального процесу по міні-фрутболу на основі диференційованого підходу в експериментальній групі відзначаємо стабільне зростання показників всіх критеріїв. Це зумовило висновок щодо педагогічної доцільності розробленої комплексної функціонально-діагностичної методики навчальнотренувальногопроцесупо міні-футболудівчат 11-14 років. Визначено, що біологічні особливості організму дівчат вимагають істотної реорганізації навчально-тренувального процесу дівчат-спортсменок 11-14 років. Необхідно здійснювати постійний контроль за здоров'ям спортсменок, зокрема за характером протікання менструальної фрункції, яка може служити важливим показником адаптаційних реакцій жіночого організму до конкретного об'єму тренувальних і змагальних навантажень [8]. Максимальна орієнтація на індивідуальні, вікові і статеві особливості спортсменки, адекватність функціональних можливостей запланованим тренувальним і змагальним навантаженням, засобам відновлення сприяють підвищенню ефективностінавчально-тренувальногопроцесу зміні-футболу дівчат-спортсменок. 3 урахуванням сучасних динамічних змін у суспільстві від фрахівця вимагається застосування варіативного підходу до виконання професійних дій і реалізувати ці складові навчально-тренувального процесу може лише тренер, що володіє високими професійними уміннями і навичками [9].

Серед безлічі чинників, що обумовлюють успішність підготовки юних футболісток, тренер, а точніше рівень його кваліфрікації, включаючи як профресійну, так і його

особистісно-психологічну відповідність вимогам діяльності, $€$ найбільш визначними [1, 2, 4]. Безумовно, і по-

вноцінне матеріально-технічне забезпечення, й ефективна організація та проведення змагань у комплексі

з іншими чинниками, сприяючими підвищенню якості учбово-тренувальної і змагальної діяльності, є важливими умовами здійснення ефективного процесу підготовки спортивного резерву у фрутболі. Але саме тренер, який певною мірою $€$ «провідником» і сполучною ланкою між накопиченими знаннями в області теорії і практики спорту з одного боку, і станом (рівнем все сторонньої підготовленості) спортсменок-фуутболісток - 3 іншого, зумовлює продуктивність різних теоретико-методичних напрацювань і ефрективність застосування сучасних технологій [3].

Нами з'ясовано вимоги до рівня професійної кваліфрікації й компетентності, а також організації професійної підготовки майбутніх тренерів-викладачів: оволодіння необхідними професійними знаннями, уміннями, навичками в галузі фізичного виховання та спорту; особистісними якостями для професійної самореалізації й саморозвитку на ринку фрізкультурно-оздоровчих і спортивно - масових послуг; відповідність освітніх програм потребам соціуму, особистості, науки та практики, спорту; створення професійно орієнтованого середовища для навчання; забезпечення високої якості практичної підготовки; орієнтація навчання на випереджувальний розвиток технологій і засобів; збереження й відновлення фізичного здоров'я населення; забезпечення можливостей для професійного розвитку. Дослідження фахівців доводять, що фундаментальна фахова підготовленість $€$ базовою для вдалої професійноїдіяльності майбутніх тренерів. Основними складниками професійної діяльності тренерів-викладачів варто вважати: фрізкультурно-спортивну діяльність (пізнавальна, організаторська, пропагандистська, інструктивнопедагогічна, суддівська); мотиваційно-ціннісні орієнтири, що виявляються в умінні мотивувати свої інтереси, переконання, потреби, прагнення досягти спортивних вершин; самодисципліну, самовиховання, саморегуляцію й самовдосконалення (рухові вміння, рухові навички, фрізичний розвиток, фізична підготовленість), що виявляються у власній спортивній досконалості та майстерності.

Отже, рівень кваліфікації тренера, об'єм його знань і наявність управлінських здібностей, що виявляються, зокрема, у визначенні завдань і здійсненні загальної координуючої функції професійної діяльності своїх помічників, і визначатиме ступінь реалізації наявного науковометодичного і матеріально-технічного потенціалу. Тому, тренер, володіючи високим рівнем спеціальних знань в області теорії і методики підготовки, а також володіючи необхідним набором особистісно-психологічних якостей і властивостей, має незрівнянно більше можливостей для успішної професійної самореалізації навіть при мінімально необхідному рівні матеріального та інших видів забезпечення $[2,5]$.

Тому, не дивлячись на те, що багато чинників, що детермінують низький рівень ефективності процесу підготовки в системі дитячо-юнацького міні-футболу в Україні, тісно взаємозв'язані і взаємообумовлені, питання формування професійної компетентності тренерських кадрів і її відповідність сучасним вимогам виділяється серед інших і $€$ одним з найбільш значущих і актуальних [2].

Перш за все, слід зазначити, що досягнення спортивної науки, які виражаються, наприклад, в удосконаленні методики тренування і пропозиції нових підходів до вирішення різних завдань підготовки спортсменів взагалі, і фрутболістів зокрема, з підвищенням рівня підготовленості тренера, його професійній компетентності пов'язані лише побічно. Оскільки програми підготовки, що розробляються, або методичні принципи тренування, що $є$ якоюсь сумою знань, є за своєю суттю лише можливістю, виступаючи як інструмент або засоби, які потенційно доступні тренерові для практичного застосування в процесі виконання своїх функціональних обов'язків. Наявні науковометодичні напрацювання ще необхідно не лише освоїти, але й критично переосмисливши, адекватно застосувати в конкретних специфічних умовах професійної діяльності тренера. Що, у свою чергу, обумовлює необхідність розглядати процес формування професійної компетентності тренера крізь призму наявності, фрормування і розвитку специфрічних особистісно-психологічних якостей і властивостей, відповідних вимогам діяльності $[3,5]$.

Основним критерієм якості підготовки майбутнього тренера-викладача $€$ його професійна компетентність. Комплекс навичок і вмінь ефеектино формується завдяки 


\section{СЛОБОЖАНСЬКИЙ НАУКОВО-СПОРТИВНИЙ ВІСНИК:}

\section{Матеріали XIX Міжнародної науково-практичної конференції «Фізична культура, спорт і здоров'я: стан, проблеми та перспективи»}

використанню на заняттях педагогічного інструментарію. До якостей тренера-викладача, що формуються в процес профресійної підготовки, на нашу думку належать такі: оволодіння значними обсягами інформації; саморозвиток та самовдосконалення в аспекті фахової підготовки; здатність самостійно вивчати спеціальну літературу; розвинене мислення; володіння спортивною культурою; здатність до планування та організації навчальної і змагальної діяльності; здійснення самоконтролю та самоаналізу; позитивне ставлення до вивчення спеціальних (фахових) дисциплін.

У проведеному дослідженні ми виокремили основн компоненти професійної компетентності: орієнтаційномотиваційний, функціональний, контрольно-оцінний Сформованість кожного компонента визначалася за певними показниками. Підтримуємо визначення, що показник $є$ певною рисою, подією або явищем, на основі якого ми доходимо висновку стосовно того, що нас цікавить, в чому ми впевнені або впевнені більше, ніж звичайно.

Проведений аналіз літературних джерел дав змогу узагальнити вимоги до вибору критеріїв, тому систематизуємо їх у такій послідовності: об'єктивність; адекватність; нейтральність щодо досліджуваних явищ; порівняння змістовність суттєво важливих показників досліджувано- го процесу чи явища; стійкість на визначеному проміжку часу

Не дивлячись на актуальну останніми роками для спорту в Україні проблему відсутності повноцінної взаємодії науки і практики, теоретична і практична значущість вивчення психологічних аспектів професійної діяльності тренера, що визначають, у свою чергу, вимоги до його особистісно-психологічної сфери не викликає сумнівів. Оскільки саме інтелектуальні здібності, ціннісні орієнтири спрямованість особистості тренера разом з іншими професійно значущими психологічними і психофрізіологічними характеристиками багато в чому обумовлюють успішність його професійної діяльності. Дані характеристики визначають не лише якісний рівень оволодіння доступними науково-методичними розробками і рівень ефективності їх практичної реалізації, але й схильність тренера до по- шуку шляхів удосконалення системи підготовки, а також до саморозвитку і самоосвіти. 3 погляду успішності виконання професійних завдань, останнє багато в чому $є$ навіть більш значущим, оскільки виступає передумовою для ефективної реалізації наявних потенційних здібностей, а також перманентного самовдосконалення фахівця [6, 10]

Враховуючи сучасні тенденції в системі дитячо- юнацького спорту, буде не зайвим звернути увагу на те, що основним критерієм успішності професійної діяльності тренера $€$ кількість підготовлених кваліфікованих спортсменок-футболісток, конкурентоздатних в умовах професійного міні-фрутболу, як на національному, так і на міжнародному рівні, а не кількість перемог в різних турнірах і вікових групах. Саме виходячи з даного положення і необхідно розглядати питання формування критеріїв оцінки професійної компетентності тренера дитячих і юнацьких команд [2,5]

Аналіз наукової літератури дав можливість визначити такі критерії сформованості компонентів розвитку професійної компетентності майбутніх тренерів-викладачів: емоційно-вольовий, когнітивний тадіяльнісний.

\section{Висновки /Дискусія}

Необхідність професійного становлення майбутніх тренерів-викладачів у процесі фахової підготовки зумовлює розв'язання педагогічних завдань щодо розвитку професійної компетентності, професійно важливих якостей, формування готовності до тренерсько-викладацької діяльності, професійного самовдосконалення та самореалізації. Ядром професійного становлення тренеріввикладачів у процесі фахової підготовки визначено розвиток професійної компетентності та професійно важливих особистісних якостей на основі узгодженості змісту фахової підготовки із специфрікою професійної діяльності тренера-викладача. Забезпечення успішного профеесійного становлення тренерів-викладачів визначено активізацію професійної мотивації; єдність змісту, форм, методів навчання; суб'єкт-суб'єктні взаємини між тренерами та вихованцями; залучення фрахівців до пошуководослідницької діяльності. Провідним $є$ формування у фахівців позитивного й усвідомленого ставлення до себе як до високого професіонала, професійної самоідентичності, усвідомленого сприйняття цінностей тренерськовикладацької діяльності, готовності до професійного саморозвитку та самореалізації.

Перспектива подальших досліджень буде направлена на аналіз та обґрунтування диференційованого підходу до побудови системи оцінки професійної компетентності тренера у вирішенні завдань підготовки спортивного резерву у міні-фрутболі залежно від змісту й спрямованості етапів багаторічної підготовки на основі сформованості компонентів розвитку професійної компетентності майбутніх тренерів-викладачів: емоційно-вольовий, когнітивний тадіяльнісний.

Конфлікт інтересів. Автори заявляють, що немає конфлікту інтересів, який може сприйматися таким, що може нанести шкоду неупередженості статті. Джерела фінансування. Ця стаття не отримала фінансової підтримки від державної, громадської або комерційної організації.

\footnotetext{
Список посилань

1. Байрачный, О.В.(2016), "Анализ современныхтребованийккомпетенциитренеравпрофессиональном футболе", Материалы XIV Международной научной сессии по итогам НИР за 2015 год, Часть 2, С.8-11.

2. Волянюк, Н.Ю. (2006), Психологічні засади професійного становлення тренера-викладача: дис... д-ра психол. наук: 19.00.01, Ін-т психології ім. Г. С. Костюка АПН України, Київ, 411 с.

3. Корх, А.Я. (2000), Тренер: деятельность и личность, Терра-спорт, Москва, 120 с.

4. Лисенчук, Г.А. (2003), Управление подготовкой футболистов, Олимпийская литература, Киев, 272 с.

5. Павлюк, Є.О. (2014), "Компоненти, критерії та рівні оцінювання професійної компетентності майбутніх тренерів-викладачів" Зб. наук. пр. Сучасні інформаційні технології та інноваційні методики навчання у підготовці фахівців : методологія, теорія, досвід, проблеми, Вип. 38, Редкол. : І. А. Зязюн (голова) та ін., Вид-во Київ-Вінниця: ТОВ фрірма «Планер», С. $377-383$.

6. Чопик, Т.В. (2012), "Аналіз професійної освіти тренера-викладача у процесі фахової підготовки", Збірник наукових праць Національної академії Державної прикордонної служби України. Серія: педагогічні та психологічні науки, Хмельницький, №62, С.144-149.
} 


\section{Матеріали XIX Міжнародної науково-практичної конференції «Фізична культура, спорт і здоров'я: стан, проблеми та перспективи»}

7. Шаповал, Є.Ю. (2012), "Теоретико-методичні аспекти формування ефективних рухових дій у жіночому міні-фрутболі",Вісник Чернігівського національного педагогічного університету. Серія : Педагогічні науки. Фізичне виховання та спорт, Чернігів, Вип. 98, (т. IV), С. 239-243.

8. Шаповал, Є.Ю. (2014) "Інтегральна підготовка як фактор реалізації принципів цілісності і послідовності тренувального процесу у жіночому міні-футболі" Фізична культура : теорія і практика : часопис кафедри теорії й методики фрізичного виховання, адаптивної та масової фрізич-ної культуриПНПУ іменіВ. Г.Короленка, Полтава, №2, С. 75-77.

9. Шаповал, Є.Ю. (2015) Формування рухових навичок дівчат 11-14 років засобами міні-футболу у дитячо-юнацьких спортивних школах: дис. канд. пед. наук: 13.00.02, Харківський нац. ун-т ім. В. Н. Каразіна, Харків, 266 с.

10. Shapoval, E.Y. (2013) Didactic essence of the differential approach to the formation of motor skills in women's mini football, Nauka i Studia. Pedagogiczne nauki. Psychologia i socjologia, Przemysl,39 (107),P. 88-93.

Стаття надійшла до редакції: 11.11 .2019 р.

Опубліковано: 30.12.2019p.

Аннотация. Шаповал Е.Ю., Голуб Л.А. Обоснование необходимости профессиональной подготовки тренеров к ведению учебно-тренировочного процесса с учетом гендерной дифференциации в женском мини-сутболе. Цель: есть обоснование путей совершенствования профессиональной деятельности будущих тренеров-преподавателей женских команд по минифутболу в новых организационно-управленческих условиях. Материал и методы: в эксперименте приняли участие 226 девушек 11-14 лет. Определены контрольная и экспериментальная группы были равномерно распределены по уровням сфформированности двигательных навыков девушек 11-14 лет путем произвольного выбора участников. Материалы исследования внедрены в учебнотренировочный процесс Коцюбинского ДЮСШ Киевской области, Коммунального заведения ДЮСШ имени А. Бутовского Полтавского областного совета, коммунального заведения ДЮСШ № 8 Харьковского городского совета, Ирпенской ДЮСШ Ирпенского городского совета. В процессе исследования використовува- лись теоретические, эмпирические и методы математической статистики для количественного и качественного анализа эмпирических данных. Результаты разработана обобщенная схема процесса формирования двигательных навыков в мини-футболе. Выяснено требования к уровню профессиональной квалифькации и компетентности, а также организации профессиональной подготовки будущих тренеровпреподавателей: овладение необходимыми профессиональными знаниями, умениями, навыками в области физического воспитания и спорта. Выводы: необходимость профессионального становления будущих тренеров- преподавателей в процессе профессиональной подготовки приводит решения педагогических задач по развитию профеессиональной компетентности, профессионально важных качеств, фрормирование готовности к тренерско-преподавательской деятельности, профрессионального самосовершенствования и самореализации.

Ключевые слова: профрессиональная деятельность, учебно-тренировочный процесс, мини-футбол, диффреренцированныйподход, двигательные навыки, девушки-футболистки.

Abstract. Shapoval E.Y., Golub L.A. Justification of the need for professional training of trainers for the conduct of the training process, taking into account gender differentiation in women's mini-football. Purpose: there is a justification of ways to improve the professional activities of future coaches and teachers of women's futsal teams in the new organizational and managerial conditions. Material and methods: 226 girls aged 11-14 took part in the experiment. The control and experimental groups were determined to be evenly distributed among the levels of motor skills of girls aged 11-14 by the arbitrary choice of participants. The research materials were introduced into the educational process of the Kotsyubynsky youth sports school in Kiev region, the municipal institution of the youth sports school named after A. Butovsky of the Poltava regional council, the public school of children's sports school No. 8 of the Kharkov city council, the Irpen youth school of the Irpen city council. In the process of research, theoretical,

empirical, and methods of mathematical statistics for quantitative and qualitative analysis of empirical data have been revealed. Results $A$ generalized scheme of the process of formation of motor skills in futsal has been developed. The requirements to the level of professional qualifications and competence, as well as the organization of professional training of future trainers, teachers: mastery of the necessary professional knowledge, skills in the field of physical education and sports. Conclusions: the need for professional development of future trainers and teachers in the process of training leads to the solution of pedagogical tasks for the development of professional competence, professionally important qualities, the formation of readiness for coaching and teaching activities, professional self-improvement and self-realization.

Key words: professional activity, educational process, futsal, differentiated approach, motor skills, female football players.

\section{References}

1. Bayrachny, O.V. (2016), "Analyz sovremennykh trebovanyi k kompetentsyy trenera $v$ professyonalnom futbole", Materyaly XIV Mezhdunarodnoi nauchnoi sessyy po itoham NYR za 2015 hod, Chast 2, S.8-11. (in Russ.)

2. Volianiuk, N.Yu. (2006), Psykholohichni zasady profesiinoho stanovlennia trenera-vykladacha: dys... d-ra psykhol. nauk: 19.00.01, In-t psykholohii im. H. S. Kostiuka APN Ukrainy, Kyiv, P.411. (in Ukr.)

3. Korkh, A.Ya. (2000), Trener: deiatelnost y lychnost, Terra-sport, Moskva, P.120. (in Russ.)

4. Lysenchuk, H.A. (2003), Upravlenye podhotovkoi futbolystov, Olympyiskaia lyteratura, Kyev, P. 272. (in Ukr.)

5. Pavliuk, Ye.O. (2014), "Komponenty, kryterii ta rivni otsiniuvannia profesiinoi kompetentnosti maibutnikh treneriv-vykladachiv", Zb. nauk. pr. Suchasni informatsiini tekhnolohii ta innovatsiini metodyky navchannia u pidhotovtsi fakhivtsiv : metodolohiia, teoriia, dosvid, problemy, Vyp. 38, Redkol. : I. A. Ziaziun (holova) ta in., Vyd-vo Kyiv-Vinnytsia: TOV firma "Planer», S. 377-383. (in Ukr.)

6. Chopyk, T.V. (2012), "Analiz profesiinoi osvity trenera-vykladacha u protsesi fakhovoi pidhotovky", Zbirnyk naukovykh prats Natsionalnoi akademii Derzhavnoi prykordonnoi sluzhby Ukrainy. Seriia: pedahohichni ta psykholohichni nauky, Khmelnytskyi, №62, S.144-149. (in Ukr.) 7. Shapoval, Ye.Yu. (2012), "Teoretyko-metodychni aspekty formuvannia efektyvnykh rukhovykh dii u zhinochomu mini-futboli", Visnyk Chernihivskoho natsionalnoho pedahohichnoho universytetu. Seriia : Pedahohichni nauky. Fizychne vykhovannia ta sport, Chernihiv, Vyp. 98, (t. IV), S. 239-243. (in Ukr.)

8. Shapoval, Ye.Yu. (2014) "Intehralna pidhotovka yak faktor realizatsii pryntsypiv tsilisnosti i poslidovnosti trenuvalnoho protsesu u zhinochomu mini-futboli" Fizychna kultura : teoriia i praktyka : chasopys kafedry teorii y metodyky fizychnoho vykhovannia, adaptyvnoi ta masovoi fizychnoi kultury PNPU imeni V. H. Korolenka, Poltava, №2, S. 75-77. (in Ukr.)

9. Shapoval, Ye.Yu. (2015) Formuvannia rukhovykh navychok divchat 11-14 rokiv zasobamy mini-futbolu u dytiacho-iunatskykh sportyvnykh shkolakh: dys. kand. ped. nauk: 13.00.02, Kharkivskyi nats. un-t im. V. N. Karazina, Kharkiv, 266 P. (in Ukr.)

10. Shapoval, E.Y. (2013) Didactic essence of the differential approach to the formation of motor skills in women's mini football, Nauka i Studia. Pedagogiczne nauki. Psychologia i socjologia, Przemysl,39 (107),P. 88-93. (in Poland) 


\section{СЛОБОЖАНСЬКИЙ НАУКОВО-СПОРТИВНИЙ ВІСНИК:}

Матеріали XIX Міжнародної науково-практичної конференції «Фізична культура, спорт і здоров'я: стан, проблеми та перспективи»

\section{Відомості про авторів / Information about the Authors} Шаповал Євгенія Юріївна: доцент, кандидат педагогічних наук; Полтавський національний педагогічний університет імені
В. Г. Короленка.

ORCID.ORG/0000-0002-3668-0875

E-mail: antenka2@ukr.net

Шаповал Евгения Юрьевна: доцент, кандидат педагогических наук; Полтавский национальный педагогический

университет имени В. Г. Короленко.

Yevheniia Shapoval: Associate Professor, Candidate of Pedagogical Sciences; Poltava National Pedagogical University named after

V.G. Korolenko.

Голуб Ліна Олександрівна: старший викладач; Полтавський національний педагогічний університет імені В. Г. Короленка.

Lina Golub: Senior Lecturer; Poltava National Pedagogical University named after V.G. Korolenko. 